\title{
Preliminary Experience with Squid: A New Liquid Embolizing Agent for AVM, AV Fistulas and Tumors
}

\author{
Squid Kullanm ile İlgili Illk Deneyim: AVM, AV Fistül ve Tümör \\ Tedavisinde Yeni Bir Srvu Embolizan Ajan
}

\author{
Ilkay AKMANGIT ${ }^{1}$, Ergun DAGLIOGLU ${ }^{2}$, Tunca KAYA ${ }^{1}$, Fatih ALAGOZ ${ }^{2}$, Mert SAHINOGLU ${ }^{2}$, \\ Ahmet PEKER ${ }^{3}$, Shehram DERAKSHANI ${ }^{4}$, Dogan DEDE ${ }^{1}$, Deniz BELEN ${ }^{2}$, Anil ARAT ${ }^{5}$ \\ ${ }_{1}^{1}$ Ankara Numune Education and Research Hospital, Department of Radiology, Ankara, Turkey \\ ${ }^{2}$ Ankara Numune Education and Research Hospital, Department of Neurosurgery, Ankara, Turkey \\ ${ }^{3}$ Ankara University, School of Medicine, Department of Radiology, Ankara, Turkey \\ ${ }^{4}$ Queen's University Hospital, Diagnostic, Interventional and Therapeutic Radiology, London, United Kingdom \\ ${ }^{5}$ Hacettepe University, School of Medicine, Department of Radiology, Ankara, Turkey
}

Corresponding Author: Ergun DAGLIOGLU / E-mail: edaglioglu@gmail.com

\begin{abstract}
AIM: The aim of the present study was to analyze our experience with a new liquid embolic agent, Squid, for the treatment of cerebral vascular lesions.

MATERIAL and METHODS: We present 28 patients who were treated with two formulations of Squid (Squid 18 and Squid 12). The lesions included 16 arteriovenous malformation (AVM)s (Spetzler-Martin grade 2 in 8, 3 in 6 and 4 in 2), 9 arteriovenous (AV) fistulas, 2 tumors (glomus tumor and angiofibroma) and 1 AICA aneurysm. Of the 9 patients presenting with hemorrhage, 6 were AVM, 2 were AVF and 1 was aneurysm. RESULTS: The total obliteration rate of the AVMs was $37.5 \%$. Fistulas were closed completely after combined treatment with surgery in 6 out of 9 patients, and one was sent to radiotherapy. There was no mortality. Two reported hemorrhages and thromboembolic complications resulted in permanent deficits in 3 patients. Pathologic examination revealed mild inflammatory reaction with infiltration of polymorphonuclear cells in 5 patients in whom surgery was performed immediately after embolization. Technical problems such as rupture, inability to remove or premature occlusion of the microcatheter related to the embolic agent were not recorded.
\end{abstract}

CONCLUSION: Squid is a safe and effective embolic agent for treatment of cerebral AVMs, AV fistulas, tumors and aneurysms with satisfactory obliteration rate.

KEYWORDS: Squid, Cerebral arteriovenous malformation, Intracranial AVM, Intracranial AV fistula, Tumor, Embolization

öz

AMAÇ: Çalışmada amaç yeni bir sıvı embolik ajan olan Squid'in serebral vasküler lezyonların tedavisindeki deneyimimizi analiz etmektir.

YÖNTEM ve GEREÇLER: Çalışmada Squid 18 ve Squid 12 olmak üzere iki ayrı Squid formülasyonu ile tedavi edilen 28 hasta sunulmaktadır. Lezyonlar arasında 16 arteriyovenöz malformasyon (AVM) (Spetzler-Martin Evre 2 olan 8, Evre 3 olan 6 ve Evre 4 olan 2 olgu), 9 arteriyovenöz (AV) fistül, 2 tümör (glomus tümörü ve anjiyofibrom) ve 1 AICA anevrizması yer almaktadır. Kanama ile prezente olan 9 hastanın 6'sı AVM, 2'si AV fistül ve 1'si anevrizmadır.

BULGULAR: AVM lezyonlarında toplam kapanma oranı \%37,5 olarak hesaplandı. Fistüllerin 9'undan 6'sı cerrahi ile kombine tedavi sonrası kapatıldı, 1 olgu radyoterapiye gönderildi. Mortalite izlenmedi. Bildirilen iki kanama ve tromboembolik komplikasyonlar 3 hastada kalıcı defisite neden oldu. Embolizasyon sonrası hemen cerrahi yapılan 5 hastadaki patolojik incelemeler, polimorfonükleer hücreleri içeren hafif enflamatuvar reaksiyonu gösterdi. Rüptür, mikrokateterin çıkarılamaması veya erken oklüzyonu gibi teknik problemler izlenmedi.

SONUÇ: Squid serebral AVM, AV fistül, tümör ve anevrizmaların tedavisinde güvenli ve efektif bir embolik ajan olup tatminkar obliterasyon oranlarına sahiptir.

ANAHTAR SÖZCÜKLER: Squid, Serebral arteriyovenöz malformasyon, İntrakraniyal AVM, İntrakraniyal AV fistül, Tümör, Embolizasyon

\section{INTRODUCTION}

Percutaneous endovascular interventions with liquid embolic agents are used either as a primary treatment of cerebrovascular arteriovenous malformation (AVM) and aneurysms or as adjuncts to surgery and/or gamma knife treatment $(2,13)$. When embolization is considered as a primary treatment modality, obliteration rates of no more than $50 \%$ can be achieved (18). Generally liquid embolic agents such as $\mathrm{N}$-butyl cyanoacrylate ( $\mathrm{n}-\mathrm{BCA}$ ) and ethylene vinyl alcohol copolymer (EVOH) are used for the endovascular management of cerebral AVMs. The use of EVOH copolymers in AVMs was first reported by Terada et al. (15). Later, Onyx was introduced and more widely used due to its slow polymerization and nonadhesive properties providing prolonged embolization times during the procedure $(7,12)$. 
Squid $^{\circledR}$ is an EVOH copolymer that has become available recently. It also has a less viscous formulation (Squid 12) for improved vascular penetration and as a lower density formulation (Squid LD) compared to Onyx. In the present study, we present the first treatment experience with this new embolic agent on 28 patients.

\section{MATERIAL and METHODS}

\section{Study Design and Clinical Characteristics}

We evaluated 28 consecutive patients who were treated with Squid ${ }^{\circledR}($ Emboflu, Switzerland) between February 2013 and December 2013 by our neurovascular team in 2 hospitals in the present study.

There were 18 female and 10 male patients. The mean age 41 years, varying between 15 and 68 years. The study population included 16 AVMs, 9 arteriovenous (AV) fistulas ( 6 dural and 3 spinal), 2 tumors and 1 cerebral aneurysm, all of which were treated with Squid as the embolic agent. In 5 of these cases, the initial plug formed by the embolic agent was enhanced with an injection of glue proximally to block the retrograde (proximal) reflux of the embolic agent over the catheter. Among the 16 AVMs, 6 presented with hemorrhage, 6 with headache, 2 with syncope, 1 with tinnitus and 1 was a recurrent lesion. The AVMs were located in the frontal lobe in 4, temporal lobe in 4, thalamochoroidal area in 3, cerebellum in 2 , occipital lobe in 1, posterior fossa/ventricle in 1, and orbit in 1 patient.

The Spetzler-Martin grade of the AVMs was 2 in eight, 3 in six and 4 in two patients. Of the 9 cerebral or spinal dural AV fistulas 2 presented with intracerebral hemorrhage, 2 with headache, 1 with tinnitus, 1 with residual fistula, 2 with paraparesis and 1 with radicular pain. The cerebral dural fistulas were located in the anterior fossa in 2, transverse sinus in 2, superior sagittal sinus in 1 and tentorium in 1 patient. Two patients were classified as $2 a$, two as $2 b$ and another two as type 4 according to the Cognard classification. The diagnosis of the three remaining patients was glomus caroticum, nasopharyngeal angiofibroma and ruptured dissecting AICA aneurysm.

\section{Technique of Embolization}

Sessions of Squid embolization were all performed under general anesthesia on a monoplane (Innova GE, USA) or biplane (Artis Zee Siemens, Erlangen, Germany) angiography unit. A 6 French (F) guiding sheath - guiding catheter coaxial system was introduced into the carotid or vertebral arteries through a common femoral artery approach and under systemic heparinization. Then the target feeder artery was catheterized with a dimethyl sulfoxide (DMSO)-compatible detachable tip micro catheter (Sonic $1.2 \mathrm{~F}$ or $1.5 \mathrm{~F}$, Balt, Montmercy, France) over a 0.007 or 0.008 inch microguidewire (Hybrid Balt, Montmercy, France). Angiographic confirmation of the tip of the microcatheter was performed and the vascular angioarchitecture was delineated for safe embolization. Before Squid injection, the microcatheter was flushed with $5 \mathrm{ml}$ saline and its dead space was filled with $0.35 \mathrm{ml} \mathrm{DMSO}$. The same volume of Squid was injected slowly for 45 seconds to substitute the DMSO in the dead space. Squid was meticulously injected into the lesion under the roadmap. The injection was stopped every 2-3 minutes to reset the roadmap. After some forward penetration, there was a tendency of Squid to reflux into the feeding artery forming a plug. Once a solid plug was formed, forward penetration of Squid into the lesion was noted (plug and push technique). Squid 12 or 18 was used depending on the degree of shunt in the AVM at the beginning. After making sure that no Squid escaped into the vein with the first injection, Squid 12 was used for further embolization due to its ability to penetrate more distally within the formed cast. The embolization was discontinued when the reflux reached the detachment zone of the microcatheter or when embolization was completed through the involved arterial pedicle. As noted above, additional glue was injected proximally in an effort to prevent further backward flow of Squid, after formation of the Squid plug in 5 cases. After complete embolization of the involved artery or lesion itself, the microcatheter was gently removed with application of gradual backward tension to achieve safe microcatheter removal. All Sonic microcatheters were successfully removed without sequela.

\section{RESULTS}

Complete obliteration of the AVM was achieved in 6 patients (37.5\% of all AVMs) at the end of the endovascular treatment (Figure 1A-D). In 5 patients (31.2\%), 75\% or more reduction was achieved in the size of the AVMs and the residual lesion was amenable to radiosurgery. Preoperative embolization was performed to obtain volumetric reduction of the AVM and to reduce the risk of intraoperative bleeding in 2 patients (12.5\%). Intraprocedural transient leak of contrast agent was detected in 2 patients (12.5\%) during Squid embolization. In 1 (6.25\%) of these patients the hematoma was resected with surgery. This patient had a modified Rankin score of 2 on follow-up. Another patient had aphasia due to a periprocedural thromboembolic event that markedly improved on follow-up. One patient's therapy is continuing.

The sections were stained with hematoxylin-eosin and Verhoeff-van Gieson for pathology examinations and revealed mild inflammatory reaction with infiltration of polymorphonuclear cells in 5 patients in whom surgery was performed immediately after the embolization. Infiltration of giant cells and mononuclear cells was noted in another patient who had undergone delayed surgical excision.

Total obliteration was achieved in 4 patients (66\%) with cerebral dural AV fistulas (Figure 2A-D). Surgery was performed and resulted in cure in 2 of these patients where small residual feeders from the cavernous ICA remained after embolization. One patient had a significant reduction of a Vein of Galen dural AVF previously treated by focal injection of glue and was subsequently referred to radiosurgery for the small residual supply. One patient is awaiting a second session of embolization. 

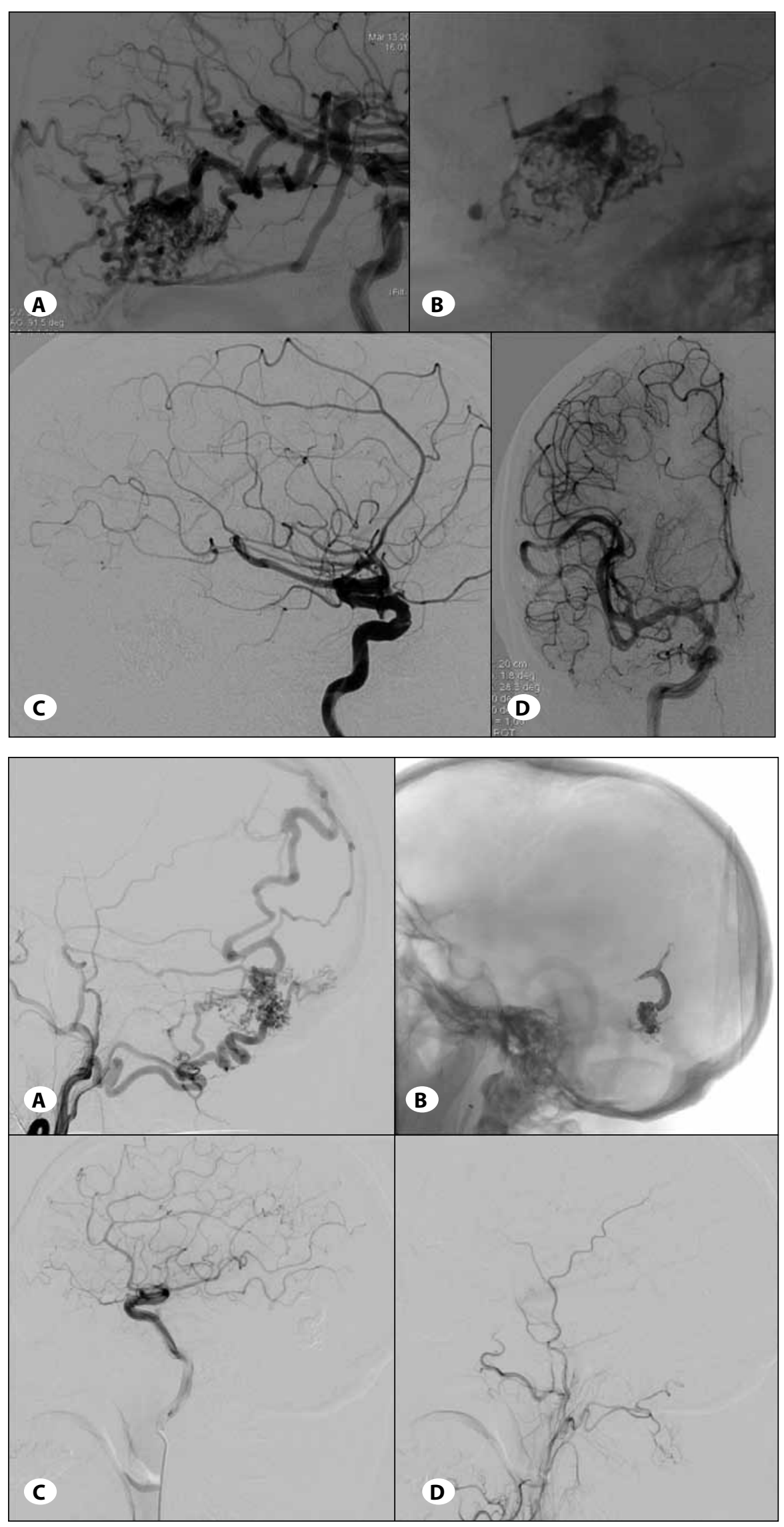

Figure 1: Right temporo-occipital AVM is demonstrated on $\mathbf{A}$ ) lateral view of a right internal carotid arteriogram and B) immediate postoperative Squid cast. C) Lateral and D) anteroposterior projections right after a single embolization sequence shows complete obliteration of the lesion after a single session of embolization with Squid.
Figure 2: A) Left external carotid arteriogram on lateral projection shows a dural AVF draining into a cortical vein. B) Squid cast is demonstrated on lateral view right after the treatment sequence. C) Follow-up angiography after 6 months shows occlusion on left internal carotid and $\mathbf{D}$ ) no residual fistula on external carotid artery angiogram. 
A ruptured dissecting AICA aneurysm was treated with the parent artery occlusion technique in 1 patient. A moderate hearing impairment was noted after complete embolization of the aneurysm (Figure 3A-D).

Preoperative embolization was also performed with Squid in two more patients with glomus caroticum and nasopharyngeal angiofibroma. The surgery was uneventful and without significant blood loss in both.

Unintended partial venous embolization of Squid during injection was observed in 1 patient. The average volume of Squid injected was $3 \mathrm{ml}$ per nidus. The mean duration of injection was 46 minutes. There was no mortality in the 28 patients included in the study. There were no retained, ruptured or prematurely clogged microcatheters.

\section{DISCUSSION}

In the present study, we presented the first experience with the clinical use of a new EVOH copolymer, Squid.
EVOH polymers have been used widely in embolization procedures with considerable success since their first introduction by Terada et al $(15,18)$. The only commercially available formulation until recent times has been Onyx produced by EV3 (Neurovascular, Irvine, CA, USA). Three different concentrations of this agent have been available (Onyx 18, 20 and 34: EVOH concentration in the composite $6 \%, 6.5 \%$, and $8 \%$ respectively). Squid has been introduced recently with 4 different formulations (18, 18LD, 12 and 12LD.) The LD versions have $30 \%$ less tantalum which may help visualize structures behind dense embolic casts under $X$ ray. The micronized tantalum particles in Squid are smaller than Onyx and allegedly provide a more homogeneous solution. We only used the 12 and 18 forms for the treatment of the target lesions in this study.

Squid 18 was preferred for initial plug formation in the embolized feeder in general and injection was commenced with Squid 12 as we observed that it penetrates more

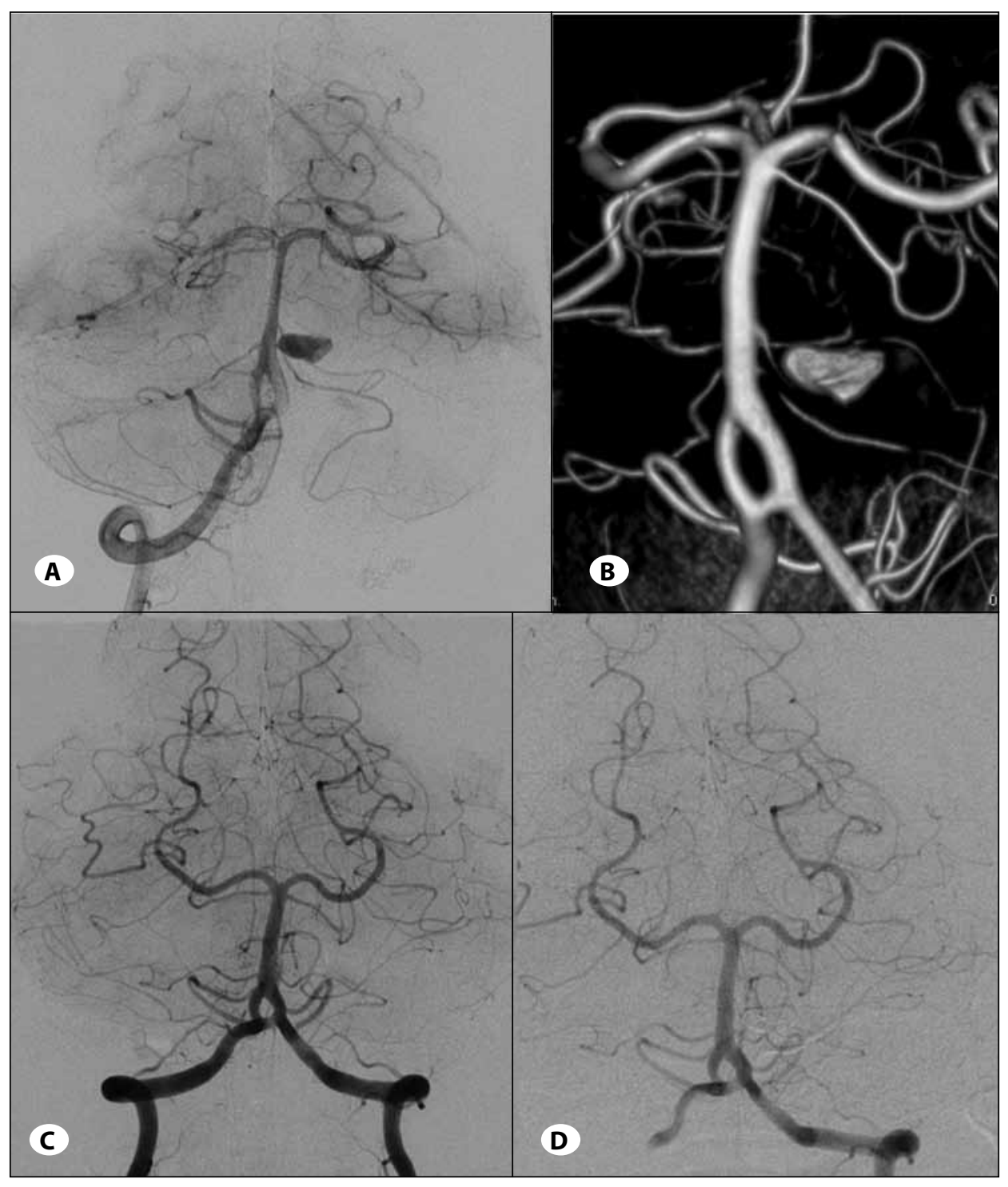

Figure 3: Left AICA aneurysm associated with a proximal basilar artery fenestration as noted on A) anteroposterior (AP) projection of right vertebral angiography and B) 3-dimensional reconstructed images obtained from rotational angiogram in a patient with subarachnoid hemorrhage. C) Postoperative and D) late follow up vertebral angiograms on AP projection after 9 months show complete occlusion of the aneurysm with Squid. 
efficiently through the embolic cast than Squid 18. In our experience, Squid 18 behavior was very similar to Onyx 18.

Complete and easy removal of the microcatheter without separation from the detachment zone was not uncommon in the present series though the number of such cases was not recorded. We did not have any stuck microcatheters after embolization. A stuck or retained microcatheter used to be a problem before the introduction of detachable tip microcatheters. Nevertheless, retained catheters are still a potential problem that may have been underreported despite the use of detachable tip microcatheters.

Premature obliteration of the microcatheter lumen, stranding at the tip of the microcatheter during withdrawal (5), and catheter entrapment despite the use of detachable tip catheters $(1,9,18)$ are potential adverse events observed during $\mathrm{EVOH}$ embolizations. We did not encounter such problems in this preliminary series.

Hemorrhage during or soon after embolization is an unintended and feared complication and might be experienced in up to $17 \%$ of the cases despite all precautions $(7,10-12,17)$ and prompt surgical intervention may be needed if bleeding does not cease. In the present series, the rate of intracranial hemorrhage during AVM treatment was reported to be $12.5 \%$ and the symptomatic hemorrhage rate was $6.25 \%$. AVM obliteration was complete in 6 of the 16 cases (37.5\%). These findings are in accordance with the results of the current Onyx series reported in the literature (18). Similarly, our total obliteration rate for dural AVFs and spinal AVFs in the absence of any permanent deficit were also satisfactory.

Distal AICA aneurysms are rare (4). Patients usually present with lower cranial nerve palsies (14). Trauma may play role in the pathogenesis of AICA aneurysms and clipping is not feasible due to the dissecting nature of these aneurysms (6, 8). Thus, parent artery occlusion is also an optional treatment for these lesions. To our knowledge, this is the first AICA aneurysm treated with a liquid embolizing agent.

Embolization is useful in hypervascular tumoral lesions to decrease the operative life-threatening bleeding risk and operation time (16). PVA, n-BCA and Onyx have been frequently used agents for tumor embolization. Angiofibroma and glomus tumors are among the most commonly embolized tumors due to their vascular nature (3). Squid was successfully used for embolization of two tumoral lesions and near complete embolization was achieved without any complication.

\section{CONCLUSION}

We presented the first experience with Squid in the treatment of AVMs, AVFs, aneurysms and tumors. We conclude that Squid is as safe and effective as its predecessor. In our experience the lower viscosity formulation (Squid 12) enabled better penetration as compared to Squid 18 or Onyx formulations.

\section{REFERENCES}

1. Arat A, Cil BE, Vargel I, Turkbey B, Canyigit M, Peynircioglu $B$, Arat YO: Embolization of high-flow craniofacial vascular malformations with onyx. AJNR Am J Neuroradiol 28(7): 1409-1414, 2007

2. Deruty R, Pelissou-Guyotat I, Mottolese C, Bascoulergue $\mathrm{Y}$, Amat D: The combined management of cerebral arteriovenous malformations. Experience with 100 cases and review of the literature. Acta Neurochir 123(3-4):101-112, 1993

3. Elhammady MS, Wolfe SQ, Ashour R, Farhat H, Moftakhar R, Lieber BB, Aziz-Sultan MA: Safety and efficacy of vascular tumor embolization using Onyx: Is angiographic devascularization sufficient? J Neurosurg 112(5):1039-1045, 2010

4. Gonzales LF, Alexander MJ, McDougall CG, Spetzler RF: Anteriorinferior cerebellar artery aneurysms surgical approaches and outcomes a review of 34 cases. Neurosurgery 55:1025-1035, 2004

5. Gore P, Theodore N, Brasiliense L, Kim LJ, Garrett M, Nakaji P, Gonzalez LF, McDougall CG, Albuquerque FC: The utility of onyx for preoperative embolization of cranial and spinal tumors. Neurosurgery 62(6):1204-1212, 2008

6. Isokangas JM, Siniluoto T, Tikkakoski T, Kumpulainen T: Endovascular treatment of peripheral aneurysms of the posterior inferior cerebellar artery. AJNR Am J Neuroradiol 29:1783-1788, 2008

7. Jahan R, Murayama Y, Gobin YP, Duckwiler GR, Vinters HV, Visual F: Embolization of arteriovenous malformations with Onyx: Clinicopathological experience in 23 patients. Neurosurgery 48:984-995, 2001

8. Lim SM, Choi IS, Hum BA, David CA: Dissecting aneurysms of the distal segment of the posterior inferior cerebellar arteries: Clinical presentation and management. AJNR Am J Neuroradiol 31:1118-1122, 2010

9. Natarajan SK1, Ghodke B, Britz GW, Born DE, Sekhar LN: Multimodality treatment of brain arteriovenous malformations with microsurgery after embolization with onyx: Singlecenter experience and technical nuances. Neurosurgery 62(6):1213-1226, 2008

10. Panagiotopoulos V, Gizewskia E, Asgaria S, Regela J, Forstinga M, Wankea I: Embolization of intracranial arteriovenous malformations with ethyl- ene-vinyl alcohol copolymer (Onyx). AJNR Am J Neuroradiol 30:99-106, 2008

11. Perez-Higueras A, Rossi Lopez R, Quinones Taria D: Endovascular treatment of cerebral AVM: Our experience with Onyx. Interventional Neuroradiology 11:141-157, 2005

12. Pierot L, Januel C, Herbreteau D, Barreau X, Drouineau J, Berge J, Sourour N, Cognard C: Endovascular treatment of brain arteriovenous malformation using Onyx: Preliminary results of a prospective multicenter study. Interventional Neuroradiology 11:159-164, 2005

13. Pierot L, Kadziolka K, Litré F, Rousseaux P: Combined treatment of brain AVMs with use of Onyx embolization followed by radiosurgery. AJNR Am J Neuroradiol 34(7):1395-1400, 2013 
14. Spallone A, De Santis S, Giuffre R: Peripheral aneurysms of the anterior inferior cerebellar artery: Case report and review of the literature. Br J Neurosurg 9:537-541, 1995

15. Terada T, Nakamura $Y$, Nakai $K$, Tsuura $M$, Nishiguchi $T$, Hayashi S, Kido T, Taki W, Iwata H, Komai NJ: Embolization of arteriovenous malformations with peripheral aneurysms using ethylene vinyl alcohol copolymer. Report of three cases. Neurosurgery 75(4):655-660, 1991

16. Van den berg $R$, Rodesch $G$, Lasjaunias P: Management of paragangliomas: Clinical and angiographic aspects. Intervent Neuroradiol 8:127-134, 2002
17. Velat GJ, Reavey-Cantwell JF, Sistrom C, Smullen D, Fautheree GL, Whiting J, Lewis SB, Mericle RA, Firment CS, Hoh BL: Comparison of $\mathrm{N}$-butyl cyanoacrylate and onyx for the embolization of intracranial arteriovenous malformations: Analysis of fluoroscopy and procedure times. Neurosurgery 63(1 Sup 1):ONS73-80, 2008

18. Weber W, Kis B, Siekmann R, Kuehne D: Endovascular treatment of intracranial arteriovenous malformations with onyx: Technical aspects. AJNR Am J Neuroradiol 28(2): 371-377, 2007 